\title{
SOME COMMENTS ON THE CURRENT (AND FUTURE) STATUS OF MUSLIM PERSONAL LAW IN SOUTH AFRICA
}

\author{
C Rautenbach*
}

\section{Introduction}

The state law of South Africa consists of the common law ${ }^{1}$ and the customary law. ${ }^{2}$ However, in reality there exist various cultural and religious communities who lead their private lives outside of state law. ${ }^{3}$ For example, the Muslim community in South Africa is a close-knit community which lives according to their own customs and usages. ${ }^{4}$ Muslims are subject to informal religious tribunals whose decisions and orders are neither recognised nor reviewable by the South African courts. ${ }^{5}$

The non-recognition of certain aspects of Muslim personal law causes unnecessary hardships, especially for women. ${ }^{6}$ A Muslim woman is often in a "catch two" situation. For example, on the one hand her attempts to divorce her husband in terms of Muslim law may be foiled by the relevant religious tribunal and, on the other hand, the South African courts may not provide the

* $\quad$ North-West University (Potchefstroom Campus), South Africa.

1 The common law of South Africa is a conglomerate of Roman-Dutch law and English law as modified by legislation.

2 Customary law is the law of the traditional communities in South Africa. It deals primarily with relationships on a horizontal level, ie relationships between private individuals. The status of customary law has been acknowledged by the Constitutional Court in Bhe $v$ Magistrate, Khayelitsha; Shibi v Sithole; South African Human Rights Commission $v$ President of the Republic of South Africa (to date unrep case no CCT 49/03; CCT 69/03; CCT 50/03 delivered on 15 October 2004).

3 For a discussion on non-state law in South Africa, see the essays contained in Schärf and Nina (eds) The Other Law.

4 See Moosa Shaping Muslim Law for a discussion of the existence of Muslim personal law within the sphere of non-state law in South Africa. As far back as 1907 there were calls for the recognition of other personal legal systems, such as Muslim personal law. See Moosa Analysis 41.

5 The Muslim community is dominated by the Ulama whose authority is only binding upon Muslim adherents.

6 For a discussion of these hardships, see Rautenbach 2003 QUTLJJ 168-169 and also Gabru 2004 PER http://www.puk.ac.za/law/per/ 1 Dec. 
necessary relief, because they might not recognise the validity of her Muslim marriage. ${ }^{7}$

Increasingly, South African courts are faced with complex issues regarding the Muslim community. ${ }^{8}$ The last few years there has been a definite change in the courts' attitude with regard to the recognition of certain aspects of Muslim personal law. Contrary to pre-1994 court cases, the recent court cases attempt to develop the common law to give recognition to certain aspects of Muslim personal law. ${ }^{9}$ This article attempts to give an overview of the recent case law that dealt with issues regarding the recognition of aspects of Muslim personal law.

Another issue, which eventuates from the current situation, is whether the South African legal order should continue to have a dualistic legal order or whether we should opt for a unified legal order or even a pluralistic legal order. ${ }^{10}$ In order to address this issue, some comments on the current status

7 In this regard s 5A of the Divorce Act 70 of 1979 might be of assistance. It reads: "If it appears to a court in divorce proceedings that despite the granting of a decree of divorce by the court the spouses or either one of them will, by reason of the prescripts of their religion or the religion of either one of them, not be free to remarry unless the marriage is also dissolved in accordance with such prescripts or unless a barrier to the remarriage of the spouse concerned is removed, the court may refuse to grant a decree of divorce unless the court is satisfied that the spouse within whose power it is to have the marriage so dissolved or the said barrier so removed, has taken all the necessary steps to have the marriage so dissolved or the barrier to the remarriage of the other spouse removed or the court may make any other order that it finds just." In Amar v Amar 1999 3 SA 604 (W) 606 the court held that the purpose of s 5A is to "create mechanisms whereby recalcitrant spouses can be encouraged or even pressurised into granting religious divorces where these are necessary to enable a spouse to remarry." The court found that the acts of the husband in casu were to withhold the get in order to compel his wife to amend an agreement between them and held that the most effective way to procure the co-operation of the husband to obtain a Jewish divorce would be to order the husband to pay maintenance to his wife until their marriage was also dissolved in terms of Jewish law. However, the section might be of no assistance to couples whose religious marriage is unrecognised in terms of South African law. They would not be able to approach a court for a divorce, because in order to obtain a divorce your marriage must be valid. See also Bonthuys 2000 SALJ 8-16 and Van Schalkwyk 2000 DJ 186-190 for a discussion of the facts of the case. See Barker 1998 DR 55-56 for a discussion of his reservations on $S 5 A$ of the act.

8 See Gabru 2004 PER http://www.puk.ac.za/law/per/ 1 Dec for a discussion of the practical problems Muslim women experience on a daily level.

9 See par 3.

10 Cachalia Muslim Family Law 31 et seq discusses three "models", which he refers to as "legal unity", "legal integration" and "legal pluralism". The first model presumes a single unified system that allows cultural and religious differences. For example, a code of 
of Muslim personal law will be made and, finally, in order to contribute to the debate regarding the recognition of Muslim personal law, optional models for the recognition of Muslim personal law will briefly be evaluated.

The author is fully aware of the complexity and sensitivity of the various issues with regard to the status of Muslim personal law in South Africa. This article does not profess to be a comprehensive and detailed discussion of the various issues concerned. It merely comments on some of the issues as identified in the court cases and finally attempts to give a brief analysis of various models for the future recognition of aspects of Muslim personal law.

\section{Muslim personal law in context}

The South African Law Reform Commission has been involved in the investigation of Muslim personal law since $1990 .{ }^{11}$ The first project committee that was appointed did not make much progress with the investigation. The reasons for the delay are not very clear. It seems that the finalisation of the Constitution $^{12}$ and a divergence of opinion on contentious issues are some of the reasons that could be advanced. The South African Law Reform Commission did not publish any of its findings for discussion.

In 1996 the South African Law Reform Commission showed renewed interest in the investigation. It decided to accord the investigation a high priority rating and recommended the appointment of a project committee. During March 1997 the South African Law Reform Commission held two workshops in order

marriage laws could provide for a minimum set of requirements for all marriages in South Africa whilst providing for the essential elements of a Muslim marriage. The second model doesn't impose one unified law, but makes provision for the integration of the legal principles of various legal systems. The Recognition of Customary Marriages Act may serve as an example of such a model. The third model denotes the formal incorporation of different systems of personal law within one legal order. The position in India may serve as an example of such a model.

11 Project 59.

12 Constitution of the Republic of South Africa 1996. 
to involve members of the public and interested parties. From 78 nominations received, the previous minister of Justice appointed a new project committee.

The new project committee under the leadership of Justice Navsa issued its first discussion document at the end of May 2000, namely Issue Paper $15 .{ }^{13}$ According to the South African Law Reform Commission its aim is to:

... investigate the legal recognition of Islamic Marriages and other aspects of Islamic Personal Law.

At the end of 2001 the South African Law Reform Commission published Discussion Paper 101. ${ }^{14}$ The closing date for comment was 31 January 2002. The discussion document contained a proposed Draft Bill on Islamic Marriages. ${ }^{15}$ The Draft Bill makes provision for, inter alia, the recognition of Muslim marriages in South Africa, ${ }^{16}$ the requirements for a valid Muslim marriage,$^{17}$ the registration, ${ }^{18}$ proprietary consequences $^{19}$ and dissolution ${ }^{20}$ of Muslim marriages and the status and capacity of spouses in Muslim marriages. ${ }^{21}$ All responses received up to and including 10 April 2000 were published by the South African Law Reform Commission in a special document referred to as "Collation of Submissions on Discussion Paper 101: Islamic and Related Matters". ${ }^{22}$ The responses were considered by the South African Law Reform Commission and the result was an amended version of

13 SALC Islamic Marriages and Related Matters (Project 59). The closing date for comment on the issue paper was the end of July 2000. Although it is not normal for the SALC to respond to submissions prior to the release of a discussion paper, it released a document containing some of the responses and the names of the respondents to Issue Paper 15. SALC Responses http://www.law.wits.ac.za/salc/issue/issue.html 1 Nov.

14 SALC Islamic Marriages and Related Matters (Discussion Paper 101) http://wwwserver.law.wits.ac.za/salc/discussn/discussn.html 1 Nov.

15 SALC Islamic Marriages and Related Matters (Discussion Paper 101) 49.

$16 \mathrm{Cl} 4$.

$17 \mathrm{Cl} 5$.

$18 \mathrm{Cl} 6$.

$19 \mathrm{Cl} 8$.

$20 \mathrm{Cl} 14$.

$21 \mathrm{Cl} 3$.

22 SALC Collation of Submissions

http://wwwserver.law.wits.ac.za/salc/discussn/collationdp101.doc 1 Nov. 
the Draft Bill ${ }^{23}$ which was included in a report ${ }^{24}$ submitted to the Minister of Justice and Constitutional Development in July $2003 .{ }^{25}$

The Draft Bill, although it underwent considerable changes, is applicable to a Muslim marriage only if the parties elected it to be applicable to their marriage. ${ }^{26}$ The Draft Bill also addresses the situation where parties were married before the commencement of the $\operatorname{act}^{27}$ and where the parties were involved in civil or customary marriages. ${ }^{28}$ The Draft Bill affords equal status to Muslim spouses ${ }^{29}$ and prescribes the proprietary consequences of a Muslim marriage. ${ }^{30}$ The Draft Bill further addresses the registration of Muslim marriages, ${ }^{31}$ the dissolution of Muslim marriages, ${ }^{32}$ custody of and access to minor children ${ }^{33}$ and maintenance. ${ }^{34}$

The general viewpoint is that the Draft Bill will alleviate the hardships that existed as a result of non-recognition of Muslim marriages. Although concerns exist regarding the non-support of the Draft Bill amongst some groupings of the Muslim community, it is generally accepted that it will eventually create certainty regarding the validity of Muslim marriages, and that it will give effect

23 Currently referred to as the Draft Bill on Muslim Marriages (the name changed from Islamic marriages to Muslim marriages).

24 SALC Report on Islamic Marriages and Related Matters 110-133.

25 The submission of the report to the minister was in terms of $s$ 7(1) of the South African Law Reform Commission Act 19 of 1973.

$26 \mathrm{Cl} 2(1)$. Cl 5 lists the requirements for a valid Muslim marriage.

$27 \mathrm{Cl} 2(2)$ - the act will be applicable to previous Muslim marriages unless the parties elected not to be bound by the provisions of the act.

$28 \mathrm{Cl} 2(4)(a)$ lays down that the act only applies to an existing civil marriage, if the parties elected it to be applicable; $\mathrm{cl} 2(4)(b)$ lay down that it does not apply to a civil marriage concluded after commencement of the act and cl 2(4)(c) lays down that it does not apply to a customary marriage registered in terms of the Recognition of Customary Marriages Act 120 of 1998.

$29 \mathrm{Cl}$ 3. The act does not purport to regulate the legal status of Muslim men and women in general.

30 Contrary to a civil marriage, which is in community of property unless an antenuptial contract stipulated otherwise, a Muslim marriage is out of community of property - see cl 8.

31 In terms of cl 8 Muslim marriages concluded before and after the commencement of the act must be registered. However, failure to register such marriage does not affect the validity of the marriage.

32 In terms of $\mathrm{cl} 9$ the Divorce Act 70 of 1979 applies to the dissolution of the marriage and includes dissolution on any ground permitted by Muslim law.

$33 \mathrm{Cl} 11$.

$34 \mathrm{Cl} 12$. 
to Muslim values. ${ }^{35}$ To date no legislation with regard to Muslim personal law have been enacted.

Until the legislation, as proposed in the Draft Bill, has been enacted the South African courts will be the forum to approach, if aggrieved Muslim parties want alleviation of the hardships caused by non-recognition of the validity of their marriages. So far the courts are continually approached by aggrieved Muslim parties who cannot wait for legislative reform in order to improve their current situation. In view of the fact that Muslim personal law (to date) receives no legislative recognition, these cases had to resort to the common law in order to seek ways to protect the interests of the aggrieved parties who approached them. In the following paragraph some of these decisions will be discussed.

\section{Viewpoints of the courts}

In terms of sections 8(3) and 39(2) of the Constitution the courts have the power to develop the common law. Such development "must promote the spirit, purport, and objects of the Bill of Rights." Up to 1997 the courts have refused to develop the common law in order to afford legal protection to parties involved in a Muslim marriage because Muslim marriages are potentially polygamous and, therefore, contra bonos mores and invalid. ${ }^{36}$ Today, however, various sections in the Constitution guarantee rights and freedoms based on culture and religion. ${ }^{37}$ These "new" values embedded in the Constitution are reflected in the recent judgments of our courts that used their newly acquired development function to develop the South African common law in order to recognise some aspects of Muslim personal law.

35 SouthAfrica.info http://www.southafrica.info/women/islamicmarriages.htm 1 Nov.

36 Rautenbach 2003 QUTLJJ 169.

37 For a discussion of these rights and freedoms, see Rautenbach, Jansen van Rensburg and Pienaar 2003 PER http://www.puk.ac.za/law/per 1 Nov. 
The first case that deviated from a long line of decisions which were all against the recognition of Muslim marriages was Ryland $v$ Edros. ${ }^{38}$ The court was prepared to develop the common law to give recognition to the contractual consequences of a Muslim marriage. ${ }^{39} \mathrm{Mr}$ Ryland (the plaintiff) and Ms Edros (the defendant) entered into a de facto monogamous Muslim marriage that did not comply with the provisions of the Marriage Act $^{40}$ and which was, therefore, invalid in terms of South African law. Plaintiff divorced defendant by serving the $\operatorname{tal} a q^{41}$ on her. Then he instituted an action in court to evict her from the house that they shared as husband and wife. Defendant defended the action and instituted a counter-claim for arrear maintenance, ${ }^{42}$ a consolatory gift $^{43}$ and an equitable portion of the growth of applicant's estate. ${ }^{44}$ She based her claim on the "contractual agreement" constituted by their Muslim marriage.

Farlam j pointed out that two preliminary questions ${ }^{45}$ had to be answered, namely whether it was appropriate for the court to pronounce upon religious matters $^{46}$ and, secondly, whether the Ismail case ${ }^{47}$ prevented the parties from relying on the marriage contract that formed the basis of their Muslim marriage.

38 Ryland v Edros 19971 BCLR 77 (C). The case was decided when the 1993 Constitution was still in force. However, s 14 of the 1993 Constitution is similar to s 15 of the Constitution, and the decision is still relevant to the interpretation of the Constitution. See also Rautenbach 2003 Koers 136-140.

39 See $696 \mathrm{C}-697 \mathrm{G}$ for the facts of the case.

40 Marriage Act 25 of 1961.

41 Talaq refers to the dissolution of a valid marriage contract by means of using the word talaq or a synonym thereof. A talaq pronounced by a husband may be two-fold: revocable and irrevocable. See Moosa Divorce 67. Definitions for irrevocable talaq and revocable talaq are also contained in $\mathrm{cl} 1$ of the Draft Bill on the Recognition of Muslim Marriages defines talaq as "the dissolution of a Muslim marriage, forwith or at a later stage, by a husband, or his wife or agent, duly authorised by him or her to do so, using the word Talaq or a synonym or derivative thereof in any language, and includes the pronouncement of a Talaq pursuant to a Tafwid al-Talaq." The Draft Bill also distinguishes between the definitions of an irrevocable and a revocable talaq.

42 For the period of their marriage.

43 Applicant alleged that the divorce was without just cause, at 696G.

44 Applicant alleged that she contributed labour, effort and money to her husband's estate and that she is, therefore, entitled to an equitable portion thereof, at $696 \mathrm{H}$.

45 701G-702A.

46 Farlam $\mathrm{j}$ refers to it as the "doctrine of entanglement".

47 Ismail v Ismail 19831 SA 1006 (A). 
With regard to the first question Farlam j pointed out that the courts, in the past, did not involve themselves in religious matters "unless some proprietary or other legally recognised right was involved". ${ }^{48}$ He argued that section 14 of the 1993 Constitution ${ }^{49}$ might have changed the position and that the doctrine of entanglement might now be part of South African law. However, since the representatives of the parties agreed that the present issues did not require the interpretation of religious issues, there was no question of doctrinal entanglement and it was, therefore, not necessary for the court to deal with the question. ${ }^{50}$

With regard to the second question Farlam $\mathrm{j}$ held that public policy was a question of fact. ${ }^{51}$ Because public policy is based on facts, it can only change if there is a change in the facts on which it is based. Since the 1993 Constitution introduced considerable changes in the factual position of public policy in South African law, it was possible to revise the Ismail case. If the "spirit, purport and objects" of the 1993 Constitution and the basic values underlying it were in conflict with the view regarding public policy, as expressed in the Ismail case, then the values underlying the 1993 Constitution had to prevail. $^{52}$ After assessing the underlying values of the 1993 Constitution the views regarding public policy as expressed in the Ismail case, the court came to the conclusion that it could not be said that the contract arising from a Muslim marriage was "contrary to the accepted customs and usages which are regarded as morally binding upon all members of our

48 703E. Quoted from Allen v Gibbs 19773 SA 212 (SE) 218A-B.

49 The wording of s 13 of the 1993 Constitution is similar to the wording of s 15 of the 1996 Constitution.

50 703B-J. It may, however, be argued that the court did indeed interpret religious issues by choosing the evidence of one expert witness over the other on the issue of division of property between the parties (715-714).

51 704B. He referred to the 1993 Constitution, which was the beginning of the new South African constitutional dispensation. According to Mahomed 1997 DR 189 it is clear that the concept of public policy is not a vague and arbitrary concept ie "... open to abuse by an executive-minded judiciary. Rather it operates within definite parameters and is guided by the interpretation provision ..." of the 1993 Constitution.

52705. 
society" or that it was "fundamentally opposed to our principles and institutions" as expressed in the Ismail case ${ }^{53}$ and said:

[1]t is quite inimical to all the values of the new South Africa for one group to impose its values on another and that the Courts should only brand a contract as offensive to public policy if it is offensive to those values which are shared by the community at large, by all rightthinking people in the community and not only by one section of it. ${ }^{54}$

Secondly, Farlam j referred to the principles of equality, diversity and multiculturalism, which conform to the values of the 1993 Constitution. In his opinion these values "irradiate" the concept of public policy that the courts have to apply. ${ }^{55}$ He differed from the viewpoint expressed in the Ismail case, namely that the contracts in issue were contra bonos mores and held:

In my opinion the 'radiating' effect of the values underlying the new Constitution $^{56}$ is such that neither of these grounds for holding the contractual terms under consideration in this case to be unlawful can be supported. ${ }^{57}$

Finally he came to the conclusion that the marriage contract between the parties was not contra bonos mores. As a result the Ismail case no longer "operates to preclude a court from enforcing claims such as those brought by" parties to an Islamic union. The court then proceeded to consider the counterclaim of the defendant and awarded her arrear maintenance after considering the facts. $^{58}$ The question of whether the defendant was entitled to a

707E (own emphasis).

$707 \mathrm{G}$.

707H-709A.

The 1993 Constitution.

709C.

711D-714F. The defendant claimed arrear maintenance from January 1977 (date of marriage) to 14 January 1993 (third month after third talaq was served). The court pointed out that the parties concluded a contract in terms of which they agreed that their marriage would be governed by Islamic law. It was common cause that the rules of the Shafi'i school are relevant in this case. Under the Shafi'i school the plaintiff is obliged to maintain his wife during their marriage and for a period of three months after talaq. It is therefore clear that plaintiff and defendant agreed (in terms of their marriage contract) that plaintiff would maintain defendant during their marriage and for three months after talaq, and that any unpaid maintenance would accumulate as a debt, and that prescription of such a debt would not be possible. The court held, however, that prescription is for the benefit of the general public and that an agreement to renounce prescription (as in this case) would be against public policy. Therefore, plaintiff is only 
consolatory gift stood over for later determination. ${ }^{59}$ Regarding the claim for an equitable share in the plaintiff's estate, the court found that the defendant could not prove that such a custom existed among the Muslim population and that her claim had to fail. ${ }^{60}$

This case is seen as one of the landmark decisions regarding the rights of Muslims in South Africa. Although it did not recognise the validity of a Muslim marriage, it did give recognition to the contractual consequences of the marriage contract between a Muslim husband and wife. Such recognition affords a Muslim wife protection when or if the marriage is dissolved. The position where there is more than one wife, that is, in a polygamous union, is still undecided.

A different conclusion was reached in the Durban High Court in Amod $v$ Multilateral Motor Vehicle Accident Fund.$^{61} \mathrm{Mr}$ and Ms Amod (the applicant) entered into a Muslim marriage, which did not comply with the requirements of the Marriage $A c t^{62}$ and was, therefore, not regarded as a valid marriage. Mr Amod was killed in a motor accident and the applicant lodged a claim for compensation for loss of support by reason of Mr Amod's death against the Multilateral Motor Vehicle Accident Fund (the respondent). The respondent denied liability on the ground of the fact that the marriage between Mr Amod and the applicant was a void Muslim marriage. The applicant contended,

liable to pay maintenance to defendant for the period from 25 October 1991 (ie three years before defendant's counter-claim was served on plaintiff's attorneys) to 14 January 1993 (ie three months after the marriage was terminated by the third talaq.)

59 714G-H. Plaintiff and defendant had to lead evidence regarding plaintiff's conduct regarding the divorce before the issue could be decided.

60 Defendant's counsel argued that defendant was entitled to an equitable portion of plaintiff's estate. He based his argument on legislation enacted in Malaysia, namely s 58 of the Malaysian Islamic Family Law (Federal Territory) Act 1984 that confers upon a court the power to order a division of assets between divorcing parties (715D-717A). The court did not accept his argument and held: "It is clear, in my view, that the Malaysian rules are based, in part at least, on Malay custom which, not being in conflict with the essential principles of Islamic law, is capable of being synthesised therewith. In view of the fact that no other Islamic country ... adopts this approach, I cannot see on what basis I can regard the Malaysian rules as being part of the provisions of Islamic personal law incorporated by the parties into their contract unless a custom similar to the Malay adat relating to harta sepencarian prevails among the Islamic community, to which the parties belong, in the Western Cape." (717B-D).

61 Amod v Multilateral Motor Vehicle Accident Fund 199712 BCLR 1716 (D). 
however, that Mr Amod had a contractual obligation (based on the marriage contract) to support her. ${ }^{63}$

The question before the court was whether the respondent was legally liable to compensate the respondent for her loss of support. In terms of South African common law, such a liability would exist if Mr Amod were, during his life, under a common law duty to support the applicant. ${ }^{64}$ However, due to the Ismail case, which held that a Muslim marriage was contra bonos mores, such a duty did not exist if the parties had been married in terms of Islamic law. ${ }^{65}$

The applicant's counsel argued, first of all, that there had been a change in public policy regarding the conclusion of Muslim marriages that had changed the traditional position. Meskin j found, however, that the onus to prove such a change rested on the applicant and that she could not prove that there had been a change of policy since the Ismail case. ${ }^{66}$

Secondly, applicant's counsel argued that the court should develop the common law to recognise a duty to support arising out of a Muslim marriage. ${ }^{67}$ Meskin $\mathrm{j}$ held that, although the facts of the case occurred before the commencement of the Constitution, it was in the interest of justice to apply the Constitution to the facts of the case. ${ }^{68}$ Upon interpretation of sections $39(2),{ }^{69}$ $8(2)^{70}$ and $8(3)^{71}$ of the Constitution he came to the conclusion that section

62 Marriage Act 25 of 1961.

63 In terms of the Muslim marriage, which is a contract, the husband is obliged to support and maintain his wife.

64 In terms of $s 31$ of the Black Laws Amendment Act 76 of 1963 a partner in a customary marriage may also claim for loss of support as a result of the death of the breadwinner.

6517191.

66 1720C.

$67 \mathrm{~S} 39(2)$ read with s 8(2) and (3) of the Constitution.

68 1722E.

69 "When interpreting any legislation, and when developing the common law or customary law, every court, tribunal or forum must promote the spirit, purport and objects of the Bill of Rights."

70 "A provision of the Bill of Rights binds a natural or a juristic person if, and to the extent that, it is applicable, taking into account the nature of the right and the nature of any duty imposed by the right."

71 "When applying a provision of the Bill of Rights to a natural or juristic person in terms of subsection (2), a court - (a) in order to give effect to a right in the Bill, must apply, or if necessary develop, the common law to the extent that legislation does not give effect to 
39(2) does not give a general power to the courts to develop the common law "to promote the spirit, purport, and objects of the Bill of Rights." The court argues that, if section 39(2) is read with sections 8(2) and (3), it is clear that the development of the common law the legislature had in mind is development

... in order to give effect to a right in the Bill ... to the extent that legislation does not give effect to that right' ... It is not intended that the Court is to have a general power of development of the common law to 'promote the spirit, purport and objects of the Bill of Rights' independently of giving effect, when applying a provision of the Bill of Rights to a natural or juristic person, to 'a right in the Bill ... to the extent that legislation does not give effect to that right. ${ }^{72}$

The applicant's counsel argued that that the right to equality ${ }^{73}$ that includes the right not to be unfairly discriminated against on the grounds of marital status or religion and the right to dignity are relevant to the facts of the case. ${ }^{74}$ Taking the facts of the case into consideration, Meskin j agreed that "a refusal to recognise the contractual duty of support upon which [the applicant] relies as being sufficient to ground the liability which she seeks to enforce constitutes, indeed, a violation" of these rights. He agrees that such refusal results in the unequal treatment of persons before the law, that is, between females lawfully married in terms of the civil law to a deceased breadwinner and those married illegally to a deceased breadwinner in terms of nonrecognised Muslim law. Although such refusal results in the unequal treatment before the law, the question is whether the court has the power to develop the common law by elimination of a principle that already forms part of it. ${ }^{75}$ The court read its power to develop the common law as restrictive, that is not to eliminate principles that already form a part of it. With reference to Du Plessis

that right; and (b) may develop rules of the common law to limit the right, provided that the limitation is in accordance with section 36 (1)."

72 S 8(3)(a). 1722H-J. In Langemaat v Minister of Safety and Security 19984 BCLR 444 ( $T$ ) Roux $j$ held that the time has arrived for recognition of a reciprocal duty of support owed by parties to a same-sex union. Such recognition is in accordance with the court's duty to promote the spirit, purport and objects of the Bill of Rights when developing the common law $(448 \mathrm{H}-\mathrm{J})$.

$73 \mathrm{~S} 9$ of the Constitution.

$74 \mathrm{~S} 10$ of the Constitution.

75 1723C-D. 
$v$ De Klerk ${ }^{76}$ Meskin j held that it is the intention of section 8(3)(a) that any alteration or elimination of the common law should remain the function of the legislature. ${ }^{77}$ The court came to the conclusion that it may not alter the existing law regarding a claim for loss of support to include a duty to support in terms of a contractual relationship resulting from a Muslim marriage, and the applicant's claim was denied. ${ }^{78}$

After the decision in Amod v Multilateral Motor Vehicle Accident Fund ${ }^{79}$ had been delivered, the applicant applied for leave to appeal directly to the Constitutional Court. The Constitutional Court found that the crucial question in the application before the court was whether the common law should be developed to allow the applicant to claim damages for support. Since it was the viewpoint of the Constitutional Court that this question is one which falls primarily within the jurisdiction of the Supreme Court of Appeal, the application for leave to appeal was dismissed. Although it could not be said that the Constitutional Court was misdirected in its findings, the reluctance (or caution) of the courts to apply the Bill of Rights directly to private relationships is illustrated.

Ms Amod (the appellant) appealed to the Supreme Court of Appeal in Amod $v$ Multilateral Motor Vehicle Accidents Fund (Commission for Gender Equality Intervening). ${ }^{80}$ On behalf of the appellant and the Commission for Gender Equality it was argued that the common law rules make provision for a claim for loss of support of a Muslim widow. In the alternative, it was argued that, if

76 Du Plessis v De Klerk 19965 BCLR 658 (CC) 691D-E: "The Lawgiver did not say that Courts should invalidate rules of common law inconsistent ... or declare them unconstitutional."

$771723 \mathrm{H}-\mathrm{I}$. See Rautenbach 2003 Koers $136-140$ for her criticism of the court's restrictive interpretation of its developmental function.

78 The court distinguished the issues of this case from the issues present in Ryland $v$ Edros 19972 SA 690 (C) and correctly held on 1726E that the court in Ryland $v$ Edros did not hold that a Muslim marriage is a lawful marriage or that it generated a legal duty to support a wife.

79 Amod v Multilateral Motor Vehicle Accident Fund 19984 SA 753 (CC).

80 Amod v Multilateral Motor Vehicle Accidents Fund (Commission for Gender Equality Intervening) 19994 SA 119 (SCA). For a discussion of the issues raised in the case see, Rautenbach and Du Plessis 2000 THRHR 302-314. 
the rules of the common law do not make such provision, the common law should be developed in terms of section 35(3) of the 1993 Constitution. ${ }^{81}$

The Multilateral Motor Vehicle Accident Fund (the respondent) alleged that an Islamic marriage does not enjoy the same status as a civil marriage, that the duty to support was a "contractual consequence of the union between them and not an ex lege consequence of the marriage per se", and that the action for loss of support should not be extended to include claims for loss of support pursuant to a contractual duty to furnish support. The action for loss of support, it was argued, should be restricted to cases in which the duty of support is one of the common law consequences of a valid marriage. ${ }^{82}$

The court found that the appellant had a good cause of action, based on the fact that the deceased had a legally enforceable duty to support the appellant; the duty arose from a solemn marriage in accordance with the tenets of a recognised and accepted faith; and that it was a duty which deserved protection and recognition for the purposes of the dependant's action. ${ }^{83}$ The question was not whether the marriage was lawful at common law, but whether the deceased had a duty to support the appellant during the subsistence of the marriage. ${ }^{84}$ The court based its findings on an "important shift in the identifiable boni mores of the community" that "must also manifest itself in a corresponding evolution in the relevant parameters of application in this area," 85 and on the test laid down in Santam v Henery. ${ }^{86}$ The court stated that the non-recognition of an action for loss of support in the case of a monogamous Islamic marriage is "inconsistent with the new ethos of tolerance, pluralism and religious freedom" 87 and held that the respondent

81 See par [5]. The 1993 Constitution was in effect when the action commenced in the court a quo.

82 Par [16].

83 Par [26] and [30].

84 Par [19].

85 Par [23].

86 Santam v Henery 19993 SA 421 (SCA) 427 H-J, 429 C-D, 430D-I.

87 Par [20]. 
was liable for damages for the loss of support suffered by the appellant in consequence of the death of her husband. ${ }^{88}$

It is important to realise that the court did not give recognition to Muslim marriages. It only extended the claim of a surviving spouse (married in terms of the common law) for loss of support to surviving spouses married in terms of unrecognised Muslim personal law. The court also did not deal with polygamous Muslim marriages, and it is uncertain whether spouses involved in such marriages would receive similar protection.

In 2003 the High Court in Daniels v Campbell, ${ }^{89}$ was invited to test, inter alia, the constitutionality of certain sections of the Intestate Succession Act ${ }^{90}$ and the Maintenance of Surviving Spouses $A c t^{91}$ in order to grant relief to a Muslim wife whose husband died intestate. Mrs Daniels (the applicant) concluded a second marriage with Mr Daniels in terms of Islamic law. The marriage was not registered in terms of the Marriage Act, but the city of Cape Town was informed of the marriage and in accordance with the then applicable policy the tenancy of the house, which was allocated to her after her divorce with her first husband, was transferred to Mr Daniels. Tenants of houses were later given the opportunity to purchase such houses and as a result Mr Daniels bought the house. The deed of sale incorrectly reflected that the couple was married in community of property. ${ }^{92}$

Mr Daniels died intestate and the house, which was his main asset, was transferred to his estate. Mr Daniels and the applicant had no children, but Mr Daniels had four children from a previous relationship. They are the fifth, sixth and seventh respondents and the late MC Daniels. In turn MC Daniels (who was predeceased) had four children, all of whom were minors when the

88 The court did not find it necessary to discuss the application of $s$ 35(3) of the 1993 Constitution or s 39(2) of the Constitution, as it was able to reach its conclusion without reliance on those provisions - see par [30].

89 Daniels v Campbell 20039 BCLR 969 (C) - hereafter referred to as the Daniels case.

90 Intestate Succession Act 81 of 1987.

91 Maintenance of Surviving Spouses Act 27 of 1990.

92 The normal consequence of a Muslim marriage is a marriage out of community. 
proceedings were instituted. The four children's mothers and natural guardians are the third and fourth respondents. After the death of Mr Daniels, the late MC Daniels and the third, fifth, sixth and seventh respondents threatened to throw the applicant out of the house.

The applicant approached the High Court for the first time in 1998 for an order declaring that she was entitled to the said house. ${ }^{93}$ The application was dismissed on various grounds that included, inter alia, the non-compliance of some of the procedural requirements by the applicant and the non-recognition of the validity of the Muslim marriage of Mr Daniels and the applicant. The court was also of the opinion that new legislation had to be promulgated in order to recognise the validity of Muslim marriages in South Africa.

The applicant then approached the High Court for a second time for an order declaring that she was a spouse $e^{94}$ for the purposes of the Intestate Succession Act and that she is, therefore, an heir in his deceased estate. ${ }^{95}$ Secondly, she applied for an order declaring that she was a survivor ${ }^{96}$ of the deceased and that she accordingly had a claim for maintenance in terms of the Maintenance of Surviving Spouses Act. To cater for the possibility that the court would refuse these orders, the applicant sought for alternative orders which provide, firstly, for a declaration of unconstitutionality of certain omissions (that is surviving Muslim spouses) in the Intestate Succession Act

93 See Daniels v Campbell 20039 BCLR 969 (C).

94 S 1(a)-(c) of the Intestate Succession Act reads as follows: "(1) If after the commencement of this Act a person (hereinafter referred to as the 'deceased') dies intestate, either wholly or in part, and - (a) is survived by a spouse, but not by a descendant, such spouse shall inherit the intestate estate; (b) is survived by a descendant, but not by a spouse, such descendant shall inherit the intestate estate; (c) is survived by a spouse as well as a descendant - (i) such spouse shall inherit a child's share of the intestate estate or so much of the intestate estate as does not exceed in value the amount fixed from time to time by the Minister of Justice by notice in the Gazette, whichever is the greater; and (ii) such descendant shall inherit the residue (if any) of the intestate estate." Own emphasis.

95 See Daniels v Campbell 20039 BCLR 969 (C).

96 S 2(1) of the Maintenance of Surviving Spouses Act states: "If a marriage is dissolved by death after the commencement of this act the survivor shall have a claim against the estate of the deceased spouse for the provision of his reasonable maintenance needs until his death or remarriage in so far as he is not able to provide therefor from his own means and earnings." Own emphasis. In terms of s 1 of the act "survivor" is defined as "the surviving spouse in a marriage dissolved by death." 
and the Maintenance of the Surviving Spouses Act and, secondly, for the "reading in" of certain provisions into the Intestate Succession Act and the Maintenance of Surviving Spouses Act in order to rectify these omissions.

Three issues arose for determination. The first issue was whether the applicant can be prevented to raise the issue of constitutionality with regard to her right to inherit in terms of the Intestate Succession Act on the grounds of the rule of res judicata, or alternatively, of the doctrine of estoppel? Although a previous application had been dismissed with costs, the court held that it could not be said that the interpretative and/or the constitutional issue in respect of the Intestate Succession Act was fully canvassed by both parties in the 1998 application, nor that the court made a final pronouncement in that application. As a result, the court held that first and second respondents reliance on res judicata and estoppel had to fail.

The second issue was whether the word "spouse", as contained in the Intestate Succession Act and the Maintenance of Surviving Spouses Act, can be interpreted to include a husband or wife married in terms of Muslim rites? The court reluctantly concluded that the word "spouse" could not be interpreted so as to include a person in the dire position of the applicant and held that the word "spouse" had to be given its "traditional, limited meaning". Van Heerden $\mathrm{j}$ was of the view that the word "spouse" only applied to spouses whose marriage was valid in terms of South African law and, accordingly, the two acts could not be interpreted to include the parties to a Muslim marriage. As a result the applicant was not a "spouse" (or "survivor") for the purposes of the acts. ${ }^{97}$

The third issue was whether the failure to define a husband or wife (who concluded a de facto monogamous Muslim marriage in accordance with Muslim rites) as a "spouse" the purpose of the Intestate Succession Act and the Maintenance of Surviving Spouses Act renders the relevant provisions of the acts unconstitutional and invalid and, if so, whether such invalidity can be 
rectified by the "reading in" of the provisions proposed by Mrs Daniels. The court agreed with the applicant's argument that the exclusion of Muslim spouses from the definition of "spouse" boils down to unfair discrimination on the grounds of equality, religion and culture which cannot be tolerated in the new constitutional order. The court could find no justification for the limitation of these rights and held that effective relief could be afforded by a suitable reading-in order that includes a surviving spouse to a monogamous Muslim marriage in the definition of spouse in the relevant acts. ${ }^{98}$

The order of the court was referred to the Constitutional Court $^{99}$ for confirmation in terms of sections $172(2)(a)^{100}$ and $167(5)^{101}$ of the Constitution. ${ }^{102}$ In the Constitutional Court it was again argued on behalf of the applicant that a proper interpretation of the word "spouse" would include Muslim spouses in the position of the applicant. The Minister supported the confirmation of the High Court order, but was not prepared to concede that the word "spouse" includes a Muslim spouse. The executors, on the other hand, contended that the word "spouse" did not include Muslim spouses and further, that the relevant provisions of the Intestate Succession Act and the Maintenance of Surviving Spouses Act are not unconstitutional. They based there contention on two facts, namely that an Imam is not barred from being registered as a marriage officer under the Marriage Act and is, therefore, not disqualified from being registered as a marriage officer and, secondly, that a

97 See the comments of Goolam and Rautenbach 2004 Stell LR 372-376.

98 Par [82].

99 Daniels v Campbell 20047 BCLR 735 (CC) at par [40].

100 S 172(2)(a) states: "The Supreme Court of Appeal, a High Court or a court of similar status may make an order concerning the constitutional validity of an Act of Parliament, a provincial Act or any conduct of the President, but an order of constitutional invalidity has no force unless it is confirmed by the Constitutional Court." Own emphasis.

101 This section reads: "The Constitutional Court makes the final decision whether an Act of Parliament, a provincial Act or conduct of the President is constitutional, and must confirm any order of invalidity made by the Supreme Court of Appeal, a High Court, or a court of similar status, before that order has any force."

102 The applicant was concerned that the Constitutional Court might refuse to confirm the declaration of invalidity and accordingly she applied for leave to appeal against the interpretation given to the word "spouse", should the application for confirmation fail. The High Court was of the opinion that a contextual and purposive reading of the act could well lead to a different order by the Constitutional Court and granted conditional leave to appeal as requested by the applicant. See par [14]. 
Muslim couple has a choice to conclude a marriage that is valid in terms of South African law.

Without much ado, Sachs j commenced his majority judgment with the observation that the word "spouse" in its ordinary meaning includes parties to a Muslim marriage. According to him the exclusion of parties to a Muslim marriage in the past emanated from a linguistically strained used of the word spouse that flowed from a "culturally and racially hegemonic appropriation of it". ${ }^{103}$ He points out that a restricted interpretation of the word "spouse" is:

... discriminatory, expressly exalting a particular concept of marriage, flowing initially from a particular world-view, as the ideal against which Muslim marriages were measured and found to be wanting. ${ }^{104}$

According to Sachs $\mathrm{j}$ the constitutional values of equality, tolerance and respect for diversity point strongly in favour of a broad and inclusive interpretation of the word "spouse". ${ }^{105}$ According to Sachs $\mathrm{j}$ the question is not whether the applicant was lawfully married to the deceased, but whether the applicant is entitled to be protected in terms of the relevant Acts. Contextual interpretations of the Acts finally lead the court to conclude that the parties to a Muslim marriage are also spouses in terms of the Intestate Succession Act or survivors in terms of the Maintenance of Surviving Spouses Act. The court clearly distinguishes this viewpoint with the conclusion reached in the cases dealing with same-sex life partners where it were found that a "spouse" did not include such a partner. ${ }^{106}$

Sachs $\mathrm{j}$ emphasises that the "inclusive" meaning he affords to the word "spouse" does not mean that there is a general recognition of the consequences of a Muslim marriage for other purposes. In other words, the broad interpretation given to the word "spouse" in terms of the relevant acts has no implications for the wider question of legislative recognition of aspects

103 Par [19].

104 Par [20].

105 Par [21]. He equates his argument with the situation in Britain where it was formerly held that the word "person" in certain legislation did not include women - see par [22] n 29. 
of Muslim personal law. ${ }^{107} \mathrm{He}$ also did not deal with the complex issues regarding polygamous Muslim marriages. ${ }^{108}$

The order of the High Court was set aside and replaced with a new order declaring the word "spouse" in the Intestate Succession Act and the word "survivor" to be broad enough to include a surviving partner to a monogamous Muslim marriage. ${ }^{109}$

To date the cases that dealt with aspects of Muslim law did it on an ad hoc basis. In most recent cases the courts have developed the common law in order to provide for protection for, especially, Muslim women who turn to them for protection. Legal certainty and adequate protection of the rights of Muslim women could only be achieved by legislative recognition of Muslim personal law. Although it seems as if the South African Law Reform Commission has decided to opt for piecemeal legislation that recognises certain aspects of Muslim law, which is Muslim marriages, there are various possibilities of how it could be done. These possibilities will be explored in the following paragraphs.

\section{$4 \quad$ Legislative recognition of Muslim personal law}

A general act, which may be referred to as the Muslim Family Law Application Act, could be enacted to give recognition to uncodified Muslim personal law. The Muslim Personal Law (Shariat) Application Act ${ }^{110}$ in operation in India could be used as an example. Section 2 of the Act applies Muslim personal law to all matters regarding

... intestate succession, special property of females, including personal property inherited or obtained under contract or gift or any other provision of personal law, marriage, dissolution of marriage, including talaq, ila, zihar, lian, khula and mubara'at, maintenance,

106 See par [28].

107 Par [26].

108 Par [36].

109 Par [40].

110 Muslim Personal Law (Shariat) Application Act 26 of 1937. 
dower, guardianship, gifts, trusts and trust properties and wakfs (other than charities and charitable institutions and religious endowments).

The act could also make provision for the institution, status and role of the Ulama, which could function in a similar way as traditional authorities in terms of customary law. The act does not have to contain substantive provisions of Muslim personal law and it could be left to either the courts or legislature to develop the substantive provisions of Muslim personal law. ${ }^{111}$

If Muslim personal law is recognised by means of a general act the Constitution will be directly applicable thereto through the intervention of the legislature. ${ }^{112}$ One of the advantages of such recognition is that Muslim personal law would be subject to the scrutiny of the Bill of Rights, which would ensure the striking down of unconstitutional rules of Muslim personal law. But approaching the courts has been a costly and time-consuming affair. There is also no guarantee that women who are discriminated against would have the means and strength to approach the courts for protection of their rights. If Muslim personal law is recognised in South Africa the question regarding jurisdiction of courts could become an important one. Would the existing courts have the jurisdiction to decide on matters of religion or would the jurisdiction of the Ulama be extended to receive binding jurisdiction similar to that of the courts of South Africa? It would also be a possibility to deal with the matter first through the Ulama, and if the parties are not satisfied with the outcome they may go to the South African courts (more or less the same as the current system of customary courts). ${ }^{113}$

Another problem emanating from the previous one has to do with the developmental function of the courts. In terms of sections 8(2), 39(2) and 173 the courts have the power to develop the common law and customary law to

111 Something similar to the common law that could either be developed by the courts or by means of legislation.

112 S 8(1) of the Constitution. The horizontal and vertical debate regarding the application of the Bill of Rights is irrelevant where legislative enactments are concerned. The common law is of general application, whilst the application of Muslim personal law will be regulated by means of legislation.

113 The same question may be asked regarding the Beth Din of the Jews. 
promote the "spirit, purport, and objects of the Bill of Rights." These sections make no mention of other legal systems that may be recognised in terms of section 15(3) of the Constitution. It is, therefore, doubtful whether the courts would have the power to develop Muslim personal law in order to promote the "spirit, purport, and objects of the Bill of Rights". The courts would, however, be entitled to strike down a rule of Muslim personal law that is unconstitutional. Declaring a rule of Muslim personal law unconstitutional without the power to develop such a rule would leave a vacuum in Muslim personal law, which could only be rectified by means of legislation or by developing the common law. ${ }^{114}$

A third problem, which could emanate from a general act recognising Muslim personal law, has to do with legal uncertainty. Currently in South Africa there is a lack of reliable sources regarding Muslim personal law. Very few universities teach the principles of religious legal systems and few scholars or court officials have any knowledge of these legal systems. It would, therefore, be risky to leave it in the hands of the judiciary and legal practitioners to determine the content of Muslim personal law in order to apply it in practice.

\section{$5 \quad$ Legislative recognition of codified Muslim personal law ${ }^{115}$}

Some of the problems caused by the previous proposal could be resolved by the codification of Muslim personal law. ${ }^{116}$ Codification would ensure the evaluation of Muslim personal law in order to conform it to constitutional demands of human dignity, equality and freedom. This task would be difficult if not impossible to achieve for a variety of reasons. In the first place Muslims argue that Muslim personal law has a divine character which renders it

114 See Rautenbach and Du Plessis 2000 THRHR 313.

115 This is proposed by Moosa 1995 Stell LR 424.

116 The recognition of Muslim personal law could be delayed until codification has been finalised or a phased approach could be followed. The latter approach entails the recognition of partly codified Muslim personal law after the finalisation of each phase. 
immutable. ${ }^{117}$ Secondly, various schools of Islamic thought exist. Which school or schools must be recognised in South Africa? ${ }^{118}$ Furthermore, the classic Muslim personal law has been modified in various dominant Muslim countries. ${ }^{119}$ Which of the many schools of which of the many versions of Muslim personal law (classic or reformed Muslim personal law) must be recognised in South Africa? Also, which branches of Muslim personal law should be recognised (for example the law of marriage, divorce and succession)?

Although the codification of Muslim personal law would obviate some of the criticisms raised in the previous proposal, the recognition of codified Muslim personal law would give rise to a plurality of legal systems, which has its own unique problems. ${ }^{120}$ However plausible, South Africa should be cautious of a plurality of legal systems. Experience in other countries has shown that such a model leads to conflict and legal uncertainty. India, which has a Muslim minority of approximately $11 \frac{1}{2} \%$, has a secular system of law that gives recognition to a variety of legal systems. As already stated, the seemingly blissful co-existence of the various legal systems leads to conflict and uncertainty and, in some instances, to the detriment of women living in India. Courts are often so caught up in issues dealing with conflict of laws that the real issues disappear in a mist of confusion and perplexity.

Other issues that must also be dealt with have to do with the conflict of laws. If Muslim personal law is recognised, persons should have the choice to opt for Muslim personal law or the law of South Africa. Problems regarding choice of

117 Faridi Islamic Personal Law 123-127. Some writers take a more liberal view. According to them, Muslim law consists of secular and religious elements. The religious element includes the five basic concepts of Islam, which are immutable and may not be changed. These concepts include Kalima (the unity of God and the prophetic character of God), Namaz (prayer five times a day), Ramajdan (feasting during certain days), Zakkadh (charity to the poor) and Jajj (pilgrimage to the holy city of Mekka). The secular element includes, inter alia, the law of crimes, the law of evidence, the law of marriage, the law of contract and the law of succession. These matters are susceptible to change and may be altered. Rathnapaki Uniform Civil Code 11-16.

118 The conflicts arising from the various denominations in Islam are clearly illustrated in Mohamed $v$ Jassiem 19961 SA 673 (A).

119 Mahmood Statutes of Personal Law 3 et seq.

120 Sinclair Law of Marriage 211-213. 
law include questions such as: Who would have the option to choose Muslim personal law? At what stage (or age) can one choose Muslim personal law? What law would be applicable when one party to a marriage chooses Muslim personal law and the other South African law? Which law will be applicable to the children of a Muslim couple? Which law will be applicable when cohabitees (one Muslim and one non-Muslim) live together or have children? What will the position be if a Muslim wants to alter his choice after he or she has chosen Muslim personal law? Would Muslim personal law be the birthright of each Muslim or not? What would happen to Muslims who were not born in SA? These are only a few of the issues that need to be addressed when a legal system decides on a plurality of legal systems.

The India experience has also shown that the co-existence of various legal systems might lead to so-called "personal law shopping." The following scenario may serve as an example: Two Hindus concluded a civil marriage in terms of the common law. The husband wants to conclude a second marriage, but in terms of the common law polygany is prohibited. However, in terms of Muslim personal law, polygany is permitted. What will happen if the husband converts to Islam in order to conclude a second Islamic marriage? And also, which legal system will apply to the first and which to the second marriage ${ }^{121}$

\section{Harmonisation of Muslim personal law with the common law}

Another possibility, which could circumvent some of the shortcomings of the previous models, is to harmonise Muslim personal law with the common law. The harmonisation of the common law with other legal systems is not a new idea. The initial aim of the South African Law Reform Commission in their

121 The prevailing circumstances in terms of customary law (the so-called discarded wife) also serve as an example of the difficulties that may be experienced if there is more than one legal system in operation. 
report on the Harmonisation of the Common Law and the Indigenous Law ${ }^{122}$ was to create "a uniform code of marriage law that would be applicable to all South Africans". The idea might be appalling to the adherents of religious legal systems. ${ }^{123}$ However, the alternative, of which India is a good example, is equally atrocious.

It is argued that the submissions of the United Ulema Council of South Africa that a phased approached regarding the recognition of Muslim personal law should be followed. ${ }^{124}$ It is suggested, therefore, that consideration should be given to piecemeal legislation recognising the various branches of Muslim personal law in phases. One of the branches that need urgent attention is the law of marriage. It is submitted that the current investigation of the South African Law Reform Commission should be done in conjunction with the existing developments taking place regarding the common law and customary law. These developments include:

(a) The enactment of the Marriage Act, Extension Act. ${ }^{125}$

(b) The investigation being done by the South African Law Reform Commission on the harmonisation of the common law and the indigenous law. ${ }^{126}$

(c) The enactment of the Recognition of Customary Marriages Act. $^{127}$

(d) The investigation being done by the South African Law Reform Commission on Islamic marriages. ${ }^{128}$

122 SALC Harmonisation of the Common Law and the Indigenous Law 8.

123 According to Labuschagne 1991 THRHR 846 uniformity will follow when human autonomy and deregulation of the marriage is recognised.

124 The United Ulema Council of South Africa is a body that consists of the major Ulema formations of South Africa. Their main objective is to act as a spokesperson for the Muslim community on national and international issues. See the submissions of the UUCSA contained in annexure C2 to the minutes of the meeting of the SALC 's workshop on Islamic Marriages and Related Matters held in Pretoria on 8 March 1997 (hereinafter referred to as the Minutes of 8 March 1997).

125 Marriage Act, Extension Act 50 of 1997. The act is retroactive from 27 April 1994 and extends the operation of the Marriage Act 25 of 1961 to the whole of South Africa.

126 SALC Report on Islamic Marriages and Related Matters 8 et seq.

127 Recognition of Customary Marriages Act 120 of 1998 . The act came into operation on 15 November 2000. 
(e) The investigation being done by the South African Law Reform Commission on the Marriage Act. $^{129}$

It is submitted that a secular marriage code that makes provision for a set of minimum requirements (dealing with the secular elements of a marriage such as age of consent, actual consent, marriage officers and registration of marriage) for all in South Africa should be considered. The celebration of the marriage could then take place according tot the religious or cultural preferences of the parties. ${ }^{130}$ Such a step would ensure equality for all South Africans before the law, whilst acknowledging cultural and religious differences; legal certainty; and the introduction of legislation to ensure that women are dealt with on an equal basis and not discriminated against within the privacy of a legal system that is excluded from the scrutiny of the Bill of Rights.

It is submitted that a previous proposal of the South African Law Reform Commission that a "marriage is an institution common to all cultures, all marriages no matter what their particular forms would exhibit certain broad similarities" is correct. It is therefore logical that a common code of marriage law for all South Africans should be developed. ${ }^{131}$ In order to give intermediate relief to the hardships caused by the non-recognition of Islamic marriages, consideration should be given to amending the Marriage Act to facilitate the recognition of Islamic marriages. ${ }^{132}$

128 SALC

Islamic

Marriages

and

Related

Matters http://www.law.wits.ac.za/salc/issue/ip15.pdf 1 Nov.

129 South African Law Reform Commission on the Marriage Act 25 of 1961. SALC Review of the Marriage Act Discussion Paper 88.

130 SALC Report on Islamic Marriages and Related Matters 17.

131 Ibid 8, 17. Although the SALC proposed separate legislation for the recognition of customary marriages they did not abandon their initial aim to investigate a single unified marriage code. They recognised the fact that their investigation might influence investigations into other unrecognised unions, such as Hindu and Islamic marriages, but in the light of urgent reform regarding customary marriages, it was decided to go ahead with their proposal to have customary marriages recognised. As a result of their proposals the Recognition of Customary Marriages Act 120 of 1998 was enacted.

132 Whether the same recognition should be afforded to polygamous Islamic marriages is a debate that falls outside the scope of this discussion. It is sufficient to point out that it is rather a question of polygyny than polygamy, because women are not allowed to marry more than one husband. The objections of Western scholars to polygyny are primarily based on religious grounds (Bronn v Fritz Bronn's Executors (1860) 3 Searle 313 318- 
Another issue that needs do be dealt with before recognition is given concerns with the obvious conflict between some rights and values contained in the Constitution. The Constitution of South Africa prohibits, among other things, discrimination on the grounds of sex and gender. On the face of it, Muslim law discriminates against females on various grounds. The half-share that benefits Muslim men in terms of the law of succession is but one example of discrimination against women that needs to be developed. ${ }^{133}$

In response, religious communities argue that the Constitution guarantees the practise of religion and culture free from interference. This obvious conflict between certain provisions of the Constitution has to be resolved before Muslim personal law can be recognised. Furthermore, discriminatory rules of Muslim personal law have to be reformed before recognition could be given to Muslim personal law. There is no doubt that some Muslims would only be satisfied with full recognition of their Muslim personal law, and there is little doubt that they will be satisfied with anything less. But they should consider codifying and reforming their personal law first, and then take something concrete to the legislature to consider. ${ }^{134}$

333; Seedat's Executors v The Master (Natal) 1917 AD 302 307-308). In Ryland v Edros 19972 SA 690 (C) 707E it was pointed out that "it is quite inimical to all the values of the new South Africa for one group to impose its values on another". There is, however, another reason why polygyny should be treated with suspicion, and that concerns the issue whether polygyny discriminates against women. The answer to the question requires, inter alia, a balancing of competing values and rights such as equality, human dignity and religious and culture-based rights. It has already been argued that equality should prevail over cultural and religion-based rights. Furthermore, polygyny is one of the characteristics of a patriarchal family system (see Sinclair Law of Marriage 167). One of the aims of the Promotion and Prevention of Unfair Discrimination Act 4 of 2000 is to eradicate inequalities caused by patriarchy. It may also be argued that the recognition of polygyny between adherents of one legal system discriminates against adherents of another legal system, which prohibits polygyny. It is doubtful whether polygyny would escape the scrutiny of the Constitution and the Promotion and Prevention of Unfair Discrimination Act 4 of 2000.

133 These issues are discussed in Rautenbach 2003 QUTLJJ 172-180. But see, Goolam 2001 Stell LR 199.

134 Poulter Separate Islamic System 165. 


\section{$7 \quad$ Conclusion}

A plurality of personal laws in South Africa should be prevented as far as possible. The South African system should be developed to accommodate the religious and cultural diversity of the country. Up to now many religious practices, such as religious marriages, were condemned by the courts and legislature due to their potentially polygynous nature. It will be very difficult for the government to substantiate why recognition is given to polygynous customary marriages whilst polygynous religious marriages are invalid due to their potentially polygynous nature. Although, at present, it is mainly the Muslim community that demands the recognition of Muslim personal law, the possibility that other religious communities in South Africa will soon follow is not excluded.

It is important to recognise and debate the issues regarding the recognition of religious legal systems from the onset. In doing so, it is important to reflect on the legal and social position of women within these legal systems before any legislative recognition is given to personal legal systems that discriminate against women.

The Draft Bill alleviates some of the problems experienced by Muslim couples as a result of the non-recognition of their marriages in South Africa. However, if the Draft Bill is enacted into legislation and it does not receive universal support from the Muslim community in South Africa, it will become mere paper law. 


\section{Bibliography}

Bonthuys 2000 SALJ

Bonthuys $E$ "Obtaining a Get in Terms of Section 5A of the Divorce Act:

Amar v Amar" 2000 SALJ 8-16

Barker 1998 DR

Barker H "New Hights in Religious Freedom" Jan 1998 DR 55-56

Cachalia Muslim Family Law

Cachalia F The Future of Muslim Family Law in South Africa (Centre for Applied Legal Studies University of the Witwatersrand Johannesburg 1991)

Faridi Islamic Personal Law

Faridi FR "Islamic Personal Law in India: Scope and Methodology of Reform" in Mahmood T (ed) Islamic Law in Modern India (NM Tripathi Bombay 1972) 123-127

Goolam 2001 Stell LR

Goolam N "Gender Equality in Islamic Family Law: Dispelling Common Misconceptions and Misunderstandings" 2001 Stell LR 199-214

Goolam and Rautenbach 2004 (2) Stell LR

Goolam N and Rautenbach C "The legal status of a Muslim wife under the Law of Succession: Is she still a hoar in terms of South African Law?"

2004 (2) Stell LR 369-380

Labuschagne 191 THRHR

Labuschagne JMT "Erkenning van die Inheemse Huwelik" 1991 THRHR 843-846

Mahmood Statutes of Personal Law

Mahmood ST Statutes of Personal Law in Islamic Countries: History, Texts and Analysis (India and Islam Research Council New Delhi 1995) 
Mahomed 1997 DR

Mahomed A "Ryland v Edros [1996] 4 All SA 557 (C)" 1997 DR 189-190

Moosa Analysis

Moosa N An Analysis of the Human Rights and Gender Consequences of the New South African Constitution and Bill of Rights (LLD thesis

University of the Western Cape 1996)

Moosa Divorce

Moosa N "Divorce" in Rautenbach C and Goolam NMI (eds) Introduction to Legal Pluralism in South Africa: Religious Legal Systems (Butterworths Durban 2002) 67-72

Moosa Shaping Muslim Law

Moosa E "Shaping Muslim Law in South Africa: Future and Prospects" in Schärf W and Nina D (eds) The Other Law: Non-State Law in South Africa (Juta Landsdowne 2001) 121-147

Moosa 1995 Stell LR

Moosa N "Muslim personal Law: To Be or not to Be?" 1995 Stell LR 417424

Poulter Separate Islamic System Poulter S "The Claim to a Separate Islamic System of Personal Law for British Muslims" in Mallat C and Connors J (eds) Islamic Family Law (Graham \& Trotman London 1990) 147-166

Rathnapaki Uniform Civil Code Rathnapaki MS Uniform Civil Code: An Ignored Constitutional Imperative (Atlantic Publishers and Distributors New Delhi 1997)

Rautenbach 2003 QUTLJJ

Rautenbach C "Gender Equality and Religious Family Laws in South Africa" 2003 (3:1) QUTLJJ 168-169 
Rautenbach 2003 Koers

Rautenbach C "Islamic Marriages in South Africa: Quo Vadimus?" 2003 (69:1) Koers 136-140

Rautenbach and Du Plessis 2000 THRHR

Rautenbach C and Du Plessis W "The Extension of the Dependant's

Action for Loss of Support and the Recognition of Muslim Marriages: The Saga Continues" 2000 THRHR 302-314

Schärf and Nina (eds) The Other Law

Schärf W and Nina D (eds) The Other Law: Non-State Law in South Africa (Jutal Landsdowne 2001)

Sinclair Law of Marriage

Sinclair JD The Law of Marriage (Juta Kenwyn 1996)

SALC Review of the Marriage Act Discussion Paper 88 South African Law Reform Commission Project 109 Discussion Paper 88 on the Review of the Marriage Act 25 of 1961 (Pretoria 1999)

SALC Islamic Marriages and Related Matters Discussion Paper 101 South African Law Reform Commission Project 59 Discussion Paper 101 on Islamic Marriages and Related Matters (Pretoria 2001)

SALC Islamic Marriages and Related Matters Discussion Paper 93 South African Law Reform Commission Project 59 Discussion Paper 93 on Islamic Marriages and Related Matters (Pretoria 2000)

SALC Report on Islamic Marriages and Related Matters South African Law Reform Commission Project 59 Report on Islamic Marriages and Related Matters (Pretoria 2003)

SALC Harmonisation of the Common Law and the Indigenous Law South African Law Reform Commission Project 90 on the Harmonisation of the Common Law and the Indigenous Law (Pretoria 1999) 
Van Schalkwyk 2000 DJ

Van Schalkwyk LN "Amar v Amar 19993 SA 604 (W)" 2000 DJ 186-190

\section{Register of court cases}

Allen v Gibbs 19773 SA 212 (SE)

Amar v Amar 19993 SA 604 (W)

Amod v Multilateral Motor Vehicle Accidents Fund (Commission for Gender

Equality Intervening) 19994 SA 119 (SCA)

Amod v Multilateral Motor Vehicle Accidents Fund 19984 SA 753 (CC)

Amod v Multilateral Motor Vehicle Accident Fund 199712 BCLR 1716 (D)

Bhe v Magistrate, Khayelitsha; Shibi v Sithole; South African Human Rights

Commission v President of the Republic of South Africa (to date unrep

case no ССТ 49/03; ССТ 69/03; ССТ 50/03 delivered on 15 October

2004)

Bronn v Fritz Bronn's Executors (1860) 3 Searle 313

Daniels v Campbell 20039 BCLR 969 (C)

Daniels v Campbell 20047 BCLR 735 (CC)

Du Plessis v De Klerk 19965 BCLR 658 (CC)

Ismail v Ismail 19831 SA 1006 (A)

Langemaat $v$ Minister of Safety and Security 19984 BCLR 444 (T)

Mohamed $v$ Jassiem 19961 SA 673 (A)

Ryland v Edros 19972 SA 690 (C)

Ryland v Edros 19971 BCLR 77 (C)

Santam Bpk v Henery 19993 SA 421 (SCA)

Seedat's Executors v The Master (Natal) 1917 AD 302

\section{Register of legislation}

Black Laws Amendment Act 76 of 1963

Constitution of the Republic of South Africa 1996

Constitution of the Republic of South Africa 200 of 1993

Divorce Act 70 of 1979

Intestate Succession Act 81 of 1987 
Maintenance of Surviving Spouses Act 27 of 1990

Malaysian Islamic Family Law (Federal Territory) Act 1984

Marriage Act 25 of 1961

Marriage Act, Extension Act 50 of 1997

Muslim Personal Law (Shariat) Application Act 26 of 1937

Promotion and Prevention of Unfair Discrimination Act 4 of 2000

Recognition of Customary Marriages Act 120 of 1998

South African Law Reform Commission Act 19 of 1973

\section{Register of Internet resources}

Gabru 2004 PER http://www.puk.ac.za/law/per/ 1 Des

Gabru N "Dilemma of Muslim Women Regarding Divorce in South Africa" 2004 (2) PER [Found on Internet] http://www.puk.ac.za/law/per [Date of use 1 December 2004]

Rautenbach, Jansen van Rensburg and Pienaar 2003 PER http://www.puk.ac.za/law/per 1 Nov Rautenbach C, Jansen van Rensburg F and Pienaar GJ "Culture (and religion) in constitutional adjudication" 2003 PER [Found on Internet] http://www.puk.ac.za/law/per [Date of use 1 Nov 2004]

\section{SALC Collation of Submissions} http://wwwserver.law.wits.ac.za/salc/discussn/collationdp101.doc 1 Nov South African Law Reform Commission Collation of Submissions on Discussion Paper 101: Islamic and Related Matters [Found on Internet] http://wwwserver.law.wits.ac.za/salc/discussn/collationdp101.doc [Date of use 1 Nov 2004] 
SALC Islamic Marriages and Related Matters (Issue Paper 15) http://www.law.wits.ac.za/salc/issue/ip15.pdf 1 Nov South African Law Reform Commission Islamic Marriages and Related Matters (Issue paper 15: Project 59 May 2000) [Found on Internet] http://www.law.wits.ac.za/salc/issue/ip15.pdf [Date of use 1 Nov 2004]

SALC Islamic Marriages and Related Matters (Discussion Paper 101) http://wwwserver.law.wits.ac.za/salc/discussn/discussn.html 1 Nov South African Law Reform Commission Islamic Marriages and Related Matters (Discussion Paper 101) [Found on Internet] http://wwwserver.law.wits.ac.za/salc/discussn/discussn.html [Date of use 1 Nov 2004]

SALC Responses http://www.law.wits.ac.za/salc/issue/issue.html 1 Nov South African Law Reform Commission Responses and the names of the respondents to Issue Paper 15 [Found on Internet] http://www.law.wits.ac.za/salc/issue/issue.html [Date of use 1 Nov 2004]

SouthAfrica.info http://www.wouthafrica.info/women/islamicmarriages.htm 1 Nov SouthAfrica.info Recognition for Islamic Marriages 1 Aug 2003 [Found on Interenet] http://www.wouthafrica.info/women/islamicmarriages.htm [Date of use 1 Nov 2004] 